\title{
O MAPA DAS CORTES E AS FRONTEIRAS DO BRASIL
}

\author{
The Map of the Courts and the Brazilian Borders
}

\author{
JORGE PIMENTEL CINTRA \\ Escola Politécnica da USP \\ jpcintra@usp.br
}

\begin{abstract}
RESUMO
Analisa-se a formação de nossas fronteiras apresentando inicialmente a questão da demarcação da linha de Tordesilhas e os problemas que levaram ao abandono desse traçado para adotar uma configuração que respeitasse tanto a posse efetiva do território (uti possidetis) como as divisas naturais: rios e divisores de água. A seguir examina-se o Mapa das Cortes que, tendo servido como base para o Tratado de Madri, determinou na prática a configuração atual de nosso país. É feita uma análise desse documento cartográfico, com o auxílio da Cartografia digital, que permitiu quantificar as distorções existentes, afirmar seu caráter propositado e descobrir a forma como foi construído.

Palavras-chave: Cartografia Histórica; Mapa das Cortes; Tratado de Tordesilhas; Cartografia Digital Aplicada a Mapas Históricos.
\end{abstract}

\begin{abstract}
The formation of our borders are analyzed, at first presenting the question of the demarcation line of Tordesillas and the problems that led to the abandonment of this trace to adopt a configuration thatwould deal with both the actual possession of the territory (uti possidetis) as the natural borders formed by rivers and water borders. Next, the Map of the Courts is examined, having served as the basis for the Treaty of Madrid, and it determines, actually, the current configuration of our country. An analysis is made of this cartographic document, with the aid of digital cartography, which yieldeds in the quantity of existing distortions, to modeled its trait and found out how it was built.

Keywords: Historic Cartography; Map of the Courts; Tordesillas Treaty; Digital Cartography Applied to Historical Maps.
\end{abstract}




\section{INTRODUÇÃO}

No imaginário nacional, as fronteiras de qualquer país formam parte da identidade da nação: a conformação do território traduzida em um mapa de seus limites, tal como uma bandeira, constitui-se num ícone que evoca imediatamente o solo nacional, e, como um símbolo, pode representar graficamente a nação e despertar sentimentos de patriotismo.

O conhecimento da morfologia do contorno e de seus limites faz parte da educação básica de cada país na área da geografia e da cartografia. De maneira semelhante, a formação dessas fronteiras constitui um capítulo importante da história nacional e associa-se a um passado tido como glorioso, quando esses limites foram se ampliando com o tempo, como é o caso do Brasil. Fatos relativos a essa conquista foram celebrados por toda a população, como o caso das vitórias do Barão do Rio Branco nas diversas questões de definição de nossas fronteiras com os países vizinhos e que se apoiaram em forte documentação cartográfica.

Assim, o presente trabalho analisa a formação de nossas fronteiras por meio do Mapa das Cortes e que, tendo servido como base para o Tratado de Madri (1750), determinou na prática a configuração atual de nosso país.

\section{PRECEDENTES}

\subsection{O Tratado e a Linha de Tordesilhas}

O Tratado de Tordesilhas, em sua linguagem redundante, pretendia especificar minuciosamente a divisão das terras entre Portugal e Espanha. Assim "reza" o trecho que estabelece a posição dessa linha:

"[...] que se faça e assinale polo dito mar oceano uma raia ou linha direita de pólo a pólo, a saber do pólo árctico ao pólo antárctico, que é de norte a sul. A qual raia ou linha se haja de dar e dê direita, como dito é, a trezentas e setenta léguas das ilhas do Cabo Verde pera a parte do ponente, por graus ou por outra maneira como melhor e mais prestes se possa dar de maneira que não sejam mais nem menos[...]".(TORDESILHAS, 1494)

Depois disso, o Tratado especifica a forma de materializar essa linha: como deveriam pilotos, astrônomos e marinheiros de ambas as nações, partindo das referidas ilhas em direção ao poente, demarcar essas léguas e, caminhando a seguir na direção norte-sul, procurar eventuais ilhas ou terra firme e nelas colocar sinais e padrões (marcos) por toda a linha divisória. Assim, na teoria tudo parecia resolvido, mas na prática os problemas logo apareceram devido a dificuldades interpretativas e técnicas.

Quanto à interpretação, a expressão ilhas do Cabo Verde faz referência a um coletivo e não especifica nenhuma em particular. A mais próxima da Europa é a de Boa Vista, e a mais próxima da América é a de Santo Antão, cuja diferença de longitude é de $2^{\circ} 42^{\prime}$. A escolha da mais ocidental, favorável a Portugal, baseia-se no fato de que qualquer outra ilha escolhida não deixaria as terras descobertas a 370 léguas das ilhas (todas) de Cabo Verde, e tem a seu favor também uma razão de 
fundo: as medições, para evitar acúmulo de erro costumavam iniciar-se nas ilhas mais afastadas da Europa e que estivessem no trajeto rumo ao destino. Por isso não se especificam as ilhas da Madeira, nem as ilhas Canárias, coisa que poderia acontecer nas viagens em direção à América Espanhola. A interpretação da contagem a partir da ilha mais ocidental foi defendida pelo geógrafo Enciso e pelo irmão de Colombo, na junta de peritos de Badajós, que se reuniu em 1524 para tratar da questão (ALBUQUERQUE, 1973).

As dificuldades técnicas residem no valor da légua e na impossibilidade de medir longitudes com precisão. Quanto ao primeiro ponto, o tratado indica que essa distância poderia ser medida em léguas ou em graus. Se a opção fossem os graus, o problema estaria resolvido teoricamente e não haveria ambiguidade. Mas, tendo sido especificada a distância em léguas, surge imediatamente a questão do tamanho da légua, pois Portugal, e também Espanha, adotaram sucessivamente os valores de 16 e 2/3 de léguas por grau; de 17 e 1/2 por grau e de 18 por grau. Essa última opção é menos provável, pois aparece pela primeira vez em 1505 na clássica obra de Esmeraldo Situ Orbe de Duarte Pacheco. Os pesquisadores da história da cartografia ainda debatem essa questão sem chegar a uma solução. Mas muitos concordam que esse problema só se coloca em nosso tempo e não na época do Tratado, pois se Portugal e Espanha não especificaram esse valor é porque era um valor certo e pacífico entre eles (GASPAR, 2010).

Não sabendo qual o valor da légua na época, pode-se trabalhar com as duas hipóteses das quantidades de légua por grau. A cada uma corresponderia uma quantidade de graus diferente para as 370 léguas: $22,20^{\circ}$ e $21,14^{\circ}$ (chega-se a esses números dividindo 370 pela quantidade de léguas por grau). Se, além disso, essas léguas forem medidas não no equador, mas na latitude de Santo Antão (17\%04'), como parece lógico, os valores em graus passam a ser: $23,22^{\circ}$ e $22,12^{\circ}$, bastando dividir os valores anteriores pelo cosseno da latitude, que é a operação usada para calcular o raio do paralelo em função do raio da terra. Para obter as duas opções de longitude para a linha de Tordesilhas deve-se somar a cada um desses valores a longitude da ponta mais ocidental da Ilha de Santo Antão com relação a Greenwich, que é $25,37^{\circ}$. Isso resulta nas longitudes extremas de $48^{\circ} 35^{\prime}$, hipótese que colocava mais terras brasileiras sob o domínio de Portugal, com a linha passando na ilha de Marajó e $47^{\circ} 28^{\prime}$, hipótese que diminuía essas terras.

Por sua vez, o cálculo de alguns cartógrafos e a posição em que colocavam essa linha em seus mapas reflete um grande desconcerto: mapas de origem portuguesa, como o de Cantino (1502) colocava o meridiano a $42^{\circ} 30^{\prime}$, posição bastante desfavorável a Portugal e mapas de origem e interesse castelhano, como o de Diogo Ribeiro (1529), português a serviço da Espanha, colocavam a linha em posição bastante inconveniente a esse país. A junta de especialistas que se reuniu em Badajós e Elvas (1524) para discutir a questão apontou a longitude de 46 30', mas não estavam muito seguros desse resultado. Passado um pouco de tempo, os mapas portugueses consolidam essa posição na foz do rio Amazonas, no que não foram contestados pelos espanhóis. Ao sul do continente o posicionamento dessa linha era 
ainda mais complicado e os mapas divergem ainda mais. São muitos os que colocam esse meridiano a oeste de Buenos Aires ou mesmo a oeste da embocadura do Paraguai no Paraná: o Atlas Miller (1515), Luis Teixeira (1574), Diogo Homem (1558) e outros, que podem ser vistos no sitio da Biblioteca Nacional (2012) e na conhecida obra Portugaliae Monumenta Cartographica, de Mota e Cortesão (1987). A Figura 1 resume graficamente o que ficou dito: os dois extremos da linha obtidos mediante o cálculo (em linha cheia) e a posição em que figura em alguns mapas. Belém do Pará e São Luis, que não existiam, estão assinaladas para efeitos de orientação.

Outro sintoma de como andavam as coisas, é a posição implícita da linha de Tordesilhas nas Cartas de Doação das Capitanias Hereditárias (1534-1536). Apesar de Martim Afonso ter plantado, em 1532, um padrão no Cabo de Santa Maria, muito próximo da atual Punta del Este, no Uruguai, o rei D. João III, baseado nas observações e medições desse futuro donatário, só fez doações ao sul até um ponto na costa, situado na latitude de $28^{\circ}$ e $1 / 3$, o que corresponde a uma localidade a meio caminho entre Imbituba e Laguna, com longitude (que se pode calcular hoje através da interseção desse paralelo com a costa brasileira) como sendo $48^{\circ} 43^{\prime}$, valor muito próximo da opção mais favorável a Portugal, segundo o cálculo acima realizado (48³5'). Mas ao norte, a doação só se estende até a abra de Diogo Leite, ou seja, à enseada segura para embarcações, descoberta na exploração que fez esse piloto da esquadra de Martim Afonso de Sousa e que corresponde aproximadamente à foz do Turiaçu, segundo alguns, ou à do Gurupi, segundo outros. Nessa última hipótese, correspondendo a $46^{\circ} 10^{\prime}$, o meridiano estaria situado muito aquém dos $48^{\circ} 35^{\prime}$ (outra hipótese de cálculo) e, mais próximo da linha dos peritos de Badajós. Essa proximidade ou afastamento são coincidências e não resultado de hipóteses de trabalho na época.

As razões desses desencontros estão na insuperável dificuldade de ordem prática: a falta de método e de equipamentos para a determinação precisa da longitude, que era avaliada por léguas percorridas, na direção leste-oeste e transformadas, depois, em graus. Para a avaliação dessas léguas, era necessário contar com a experiência dos pilotos e suas regras empíricas; por exemplo, o Regimento das léguas - documento em uso a partir do século XV que indicava como calcular as léguas percorridas na prática da navegação - fornecia, para 24 horas, com vento teso em popa, de 36 a 38 léguas; com vento, quando a nau governa pela bolina, 8 léguas. Como a nau andava em ziguezague, era necessário efetuar as reduções através de fórmulas dadas por esse Regimento (MARQUES, 1994). Como se vê, trata-se de um método de baixa precisão. E por isso, o parecer de Hernando Colombo, irmão de Cristóvão, era que não havendo nenhum método preciso que permitisse uma localização exata, nenhum argumento poderia ser conclusivo e, portanto, "nenhuma das partes poderá convencer a que quiser tergiversar". Além disso, misturavam-se interesses no antimeridiano, isto é, na região das Filipinas e Molucas, que faziam com que fosse melhor para Portugal empurrar o meridiano de 
Tordesilhas mais para o Atlântico, perdendo aqui e ganhando lá (THEODORO e RUIZ, 2004).
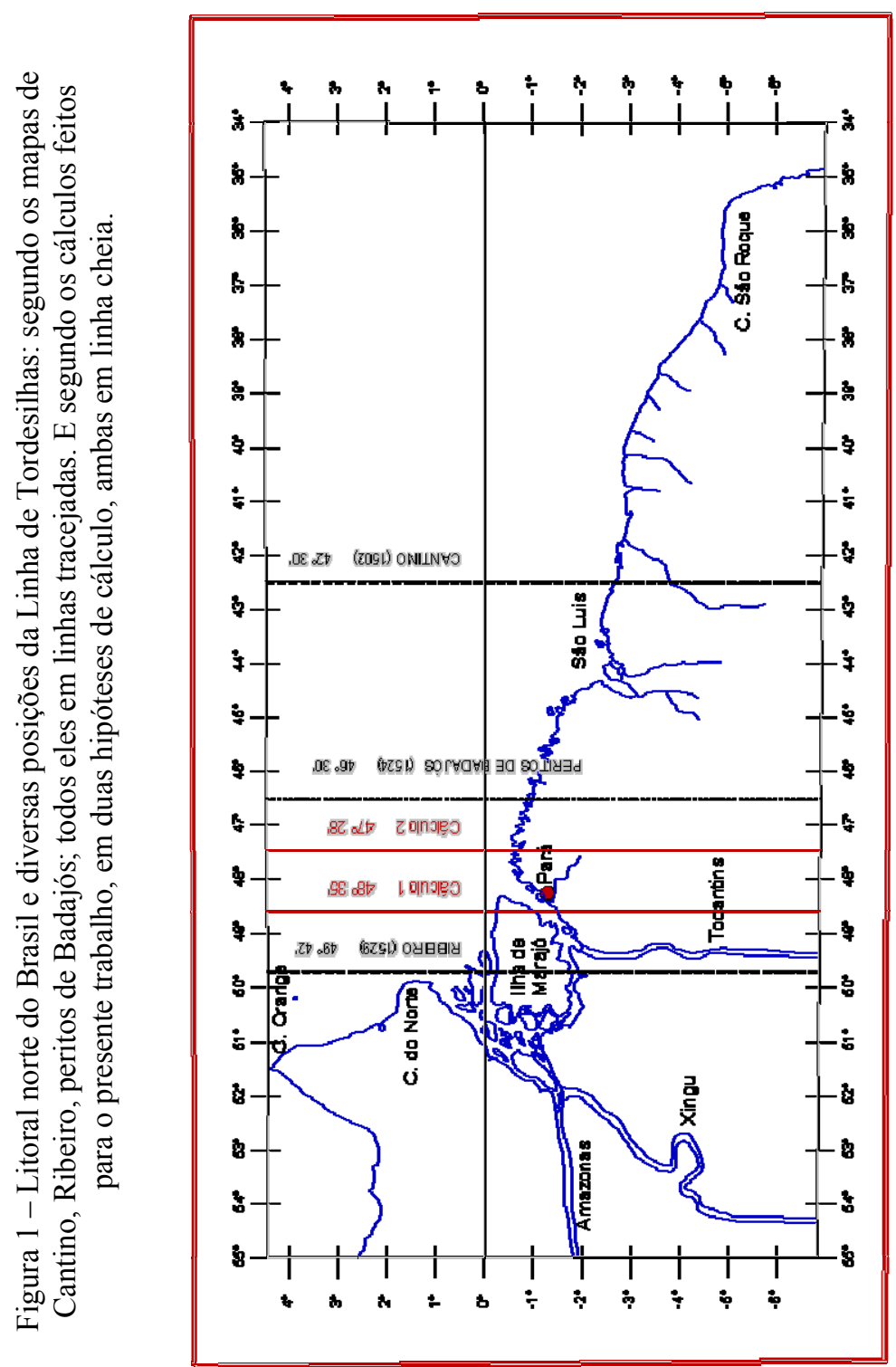

Bol. Ciênc. Geod., sec. Artigos, Curitiba, v. 18, nº 3, p.421-445, jul-set, 2012. 
Métodos precisos de medição só viriam mais tarde: aquele que observa as ocultações dos satélites de Júpiter, proposto por Galileu em 1610, só se tornaria prático para observações em terra, após a publicação das tábuas de efemérides desses astros por Cassini, em 1668. Já o método das diferenças horárias só se tornaria viável após a invenção do cronômetro por Harrison em 1735, e de forma prática só no último quartel desse século (MORAES, 1984).

Em todo caso, nos mapas de Portugal foi-se consolidando uma Linha de Tordesilhas que passava ao norte na embocadura do Amazonas e ao sul no estuário do rio da Prata: a partir de 1519, por ordem expressa de D. Manuel, os mapas portugueses deveriam ser deformados para dar a entender que toda a bacia do Prata pertencia a Portugal (CORTESÃO, 1955). Paralelamente iniciou-se uma política de fatos consumados.

\subsection{O Princípio do Uti Possidetis}

Com essa indefinição da linha divisória, o Tratado foi pouco eficaz do ponto de vista demarcatório e prevaleceu mesmo a ocupação efetiva do território. Os espanhóis, em regiões que seriam suas, mas sem terem absoluta certeza, chegaram a ocupar posições no oeste do estado de São Paulo e norte do Paraná e do Rio Grande do Sul. Concretamente, estabeleceram, através dos jesuítas, as Missões do Guairá (1612-1628) e do Tape (1626-1635), os chamados Sete Povos das Missões. Já os portugueses fundaram e ocuparam ao sul a Colônia Sacramento (1648) e ao norte o forte de Belém (1616), como forma de defesa contra as invasões francesas, holandesas e inglesas, por indicação do próprio soberano da Espanha, que nessa época, conhecida como das duas coroas, também regia Portugal.

Assim, o Tratado de Tordesilhas serviu para que Portugal e Espanha não entrassem em conflitos armados e pouco valeu perante outras nações, como era de esperar. Ocupações ocorreram em toda a América e foi essa ocupação de fato, com uso ou não da força, que definiu a posse dos territórios, por parte da Inglaterra, França, Holanda, além das tentativas de alemães.

$\mathrm{Na}$ expansão sobre o território, sem se importar com uma linha imaginária, destacaram-se os bandeirantes, que partiram de São Paulo em fins do século XVI. Penetraram em diversas direções na busca de prata e ouro, que não encontraram num primeiro momento, dedicando-se então à caça dos índios, preferencialmente nos aldeamentos jesuíticos, que destruíram, tanto no Guairá (1628) como no Tape (1635). No final desse século descobriram o ouro em Minas Gerais (1695) e a seguir em Cuiabá (1718) e Goiás (1725). Diversos são os roteiros pelos vales do São Francisco, Tocantins, e Paraguai, com destaque para o périplo de Raposo Tavares (1647-1651), incluindo em seu trajeto a vias fluviais do Guaporé, Mamoré, Madeira e Amazonas. Isso foi caracterizando uma precedência portuguesa na descoberta, o traçado de caminhos terrestres ou fluviais (as chamadas monções), e certa ocupação e posse do território, configurando as fronteiras sul e oeste com a América espanhola. 
Já na região norte deve-se destacar a expedição de Pedro Teixeira (16371639), que remontou até Quito e plantou um padrão de posse portuguesa na foz do Japurá. E também a ocupação efetiva através dos exploradores das drogas da Amazônia e, sobretudo, a instalação das missões carmelitas ao longo do Amazonas e do Negro (1695-1697) e dos jesuítas no Tapajós e no Madeira (1687). Por sua parte, os missionários espanhóis estabeleceram as missões jesuíticas, do alto Amazonas até as proximidades do rio Javari (1684-1688). Com isso se fechava o arco básico das futuras fronteiras pelo oeste e norte e que ficarão refletidas no Mapa das Cortes e no Tratado de Madri.

Por outro lado, sabe-se que a União Ibérica (1580-1640) - duas nações com dois Conselhos e um só rei - tornou menos premente a demarcação de uma linha de fronteira. A união de esforços tornou-se imperiosa em função da defesa do litoral contra franceses e holandeses, que de fato conquistaram territórios portugueses. A construção de fortes, como o de Belém (1616), Gurupá (1623) e Paru (1623), e a criação de novas Capitanias, como as de Cametá (1620), Cumá (1633), Gurupi (1634) e do Cabo Norte (1637); e o fato de seu governo ter sido confiado pelo rei aos portugueses, caracterizou a posse portuguesa, de direito e de fato, de toda a região ocupada. Separadas as duas nações, o fato estava consumado.

As invasões e ocupações territoriais, como as da Espanha na Colônia Sacramento (em 1680, 1705 e 1735), foram resolvidas mediante cláusulas em tratados que dispunham o retorno da posse, tal como estava antes, tal como se possuía antes do conflito; ou seja, reconheciam que a posse é um indício de direito. Admitia-se assim um novo princípio regulador da posse da terra, o uti possidetis, que em sua tradução literal significa tal como possuis: o direito respeita a posse, ou seja, a ocupação efetiva da terra. Foi esse princípio que prevaleceu no Tratado de Madri (1750).

\subsection{O Esforço Cartográfico Visando ao Tratado de Madrid}

Para Portugal, as descobertas das minas de ouro, e especialmente as de Cuiabá (1718), tornaram premente uma definição de fronteiras que assegurasse o domínio e a posse pacífica dessa região. Para a Espanha, a existência da Colônia Sacramento, no estuário do Prata, tornava essas águas internacionais e era fonte de grande contrabando da prata que escoava por essa via fluvial. Dessa forma, essa nação estava disposta a realizar uma troca de terras, mesmo que um pouco desvantajosa, que lhe assegurasse a posse dessa cidade e seu território e, portanto, a soberania e o controle da navegação do rio da Prata; a Portugal seria concedido um território proporcional, o território das Missões, e não se contestariam a soberania e o controle da navegação portuguesa na Amazônia, que já vinha ocorrendo.

Pensando num futuro tratado, em Portugal, homens de visão como Dom Luis da Cunha e Alexandre de Gusmão, compreenderam a necessidade imperiosa de contar com bons mapas para poder elaborar um Tratado em que se soubesse o que estava em jogo: o que se ganhava e o que se perdia, em termos de área, e por onde deveria passar uma nova linha divisória que respeitasse as áreas já ocupadas. 
Houve, assim, um grande impulso à cartografia e ao conhecimento do território, aproximadamente a partir de 1730, que se concretizou em várias medidas: o aproveitamento de todo material que pudesse servir de informação para a elaboração de cartas; relatos e roteiros de índios, bandeirantes e sertanistas; estudo de mapas existentes, notadamente os elaborados por cartógrafos não portugueses e que teriam assim especial autoridade diante da Espanha, estando entre eles os mapas do padre Fritz, de Delisle, de La Condamine, de José da Silva Pais, de Freire de Andrade; e principalmente a contratação e a formação de cartógrafos que pudessem medir coordenadas geodésicas de pontos (latitude e longitude) e elaborar mapas precisos: para isso, vieram contratados ao Brasil, os padres Matemáticos, jesuítas versados em astronomia e cartografia. Finalmente, contou-se com a colaboração do melhor cartógrafo da época, Jean Baptiste Bourguignon D'Anville, para a elaboração de um mapa síntese (CORTESÃO, 2006).

O itinerário, em direção a uma cartografia de síntese, inicia-se com os trabalhos do real cartógrafo francês Guillaume Delisle, que lera sua dissertação perante a Academia Real de Ciências de Paris (1720) e publicara um mapa, que incluía o novo continente: baseava-se em longitudes astronômicas e corrigia, portanto, muitas imperfeições, propositadas ou não, dos antigos mapas portugueses. Para a América do Sul, Delisle baseava-se nas coordenadas de três pontos fundamentais: dois medidos pelo padre Feuillée em 1705 na costa norte de nosso continente (Cartagena de Índias e Porto Belo) e um em Recife (Ilha de Antonio Vaz) correspondente às observações do astrônomo holandês Jorge Marcgrave (16391642), quando da ocupação batava do nordeste brasileiro. Vale destacar que a França estava na fronteira do conhecimento em cartografia, nos tempos de Luis XIV, devido a uma série de medidas: criação da Academia de Ciências, do Observatório de Paris, da contratação de grandes cientistas como Cassini, que elaborou tabelas dos eclipses dos satélites de Júpiter e assim viabilizou o método de determinação de longitudes proposto por Galileu.

Essa leitura de Delisle provocou enorme escândalo, pois denunciava a extralimitação portuguesa em terras da Espanha e da França, na América meridional. Em seus cálculos e estudos, mostrava que os mapas portugueses situavam a costa brasileira a uns 2 ou 3 graus da linha de Tordesilhas quando, na realidade, situa-se a uns 9 graus. Para obter esse valor, bastava calcular a diferença entre a longitude de Santo Antão (27 $40^{\prime}$ ), com o valor obtido por Marcgrave $\left(36^{\circ} 20^{\prime}\right)$, para a costa brasileira, ambos referidos ao meridiano de Paris. Em um mapa associado à sua dissertação, Delisle mostrava o meridiano de Tordesilhas passando, ao norte, cerca de Belém do Pará e, ao sul, na desembocadura da Lagoa dos Patos, e assim deixava de fora a Colônia Sacramento. Portugal protestou contra essa nova cartografia, mas sabia que, mesmo assim, essa era uma posição favorável em relação à posição real ao sul, pouco abaixo da atual Imbituba, como se fez notar. Essa nova posição da linha, ainda a favor de Portugal, seria utilizada na elaboração do Mapa das Cortes. 
O Mapa das Cortes é um mapa-síntese, que se apóia em dezenas de fontes, mas diverge de mapas mais precisos já disponíveis em Portugal, como o de D'Anville, e realiza uma composição deformada que torna a morfologia mais favorável à aprovação do Tratado. Ou seja, causou nos negociadores uma impressão de uma menor perda territorial por parte da Espanha, como se verá após examinar as principais fontes desse mapa.

\section{4 O Mapa de La Condamine}

Outro cientista e cartógrafo, cujo trabalho influenciou decisivamente na elaboração do Mapa das Cortes, foi Charles Marie de La Condamine. Enviado pela Academia de Ciências, com outros companheiros para medir um arco de meridiano no Peru, ao terminar a tarefa, resolveu descer o rio das Amazonas, do seu trecho inicial navegável (Jaén de Bracamoros), até a foz (1743-1744). Sobre essa expedição, (La Condamine, 2000), escreveu um relato em que determinou latitudes e longitudes por métodos astronômicos e elaborou um mapa (Figura 2) que foi considerado como o mais preciso até então da região amazônica e, em particular, desse curso dágua.

Apesar do compromisso de fornecer a Portugal os dados e mapas, para o que foi autorizado e financiado, chegado que foi a Paris, apressou-se a ler em sessão pública na Academia de Ciências uma memória resumida e publicou um mapa em que denunciava, como Delisle, a invasão portuguesa nos domínios amazônicos de Castela e da França, baseado na posição da linha de Tordesilhas e na longitude de Belém. Portugal novamente tomou suas medidas políticas, mas o fato é que esse mapa incluía um erro superior a $3^{\circ}$ na foz do rio Napo, produzindo um encurtamento dessa mesma magnitude na região ocupada pelos portugueses no vale amazônico: era assim outro erro favorável às pretensões portuguesas, provindo de fontes confiáveis para a Espanha, e que seria habilmente explorado na elaboração do Mapa das Cortes. Uma análise detalhada do mapa de La Condamine pode ser vista em Cintra e Freitas (2011).

Paralelamente, Portugal vinha trabalhando na construção da cartografia do Brasil. Além de recolher todos os mapas possíveis, contratou e formou astrônomos que pudessem determinar latitudes e longitudes, com precisão. Assim, vieram ao Brasil os chamados padres matemáticos, jesuítas que trabalharam em diferentes regiões: Cocleo (década de 1670, em Minas Gerais), Pfeil (1679, no Pará e Amazonas), e, principalmente, Soares e Capacci (1729) que determinaram mais de 200 pontos precisos e elaboraram mapas desde a Colônia Sacramento até Minas Gerais. Posteriormente, em 1742, Portugal contratou Bourguignon D'Anville, principal cartógrafo francês, para realizar uma síntese de todos os conhecimentos existentes, que redundou na produção de um mapa em 1748: a Carte de l'Amérique Méridionale, que, por ser preciso e contrário aos interesses portugueses, só foi divulgado após a assinatura do Tratado. Para uma análise detalhada desse mapa veja-se Cintra e Furtado (2011). 


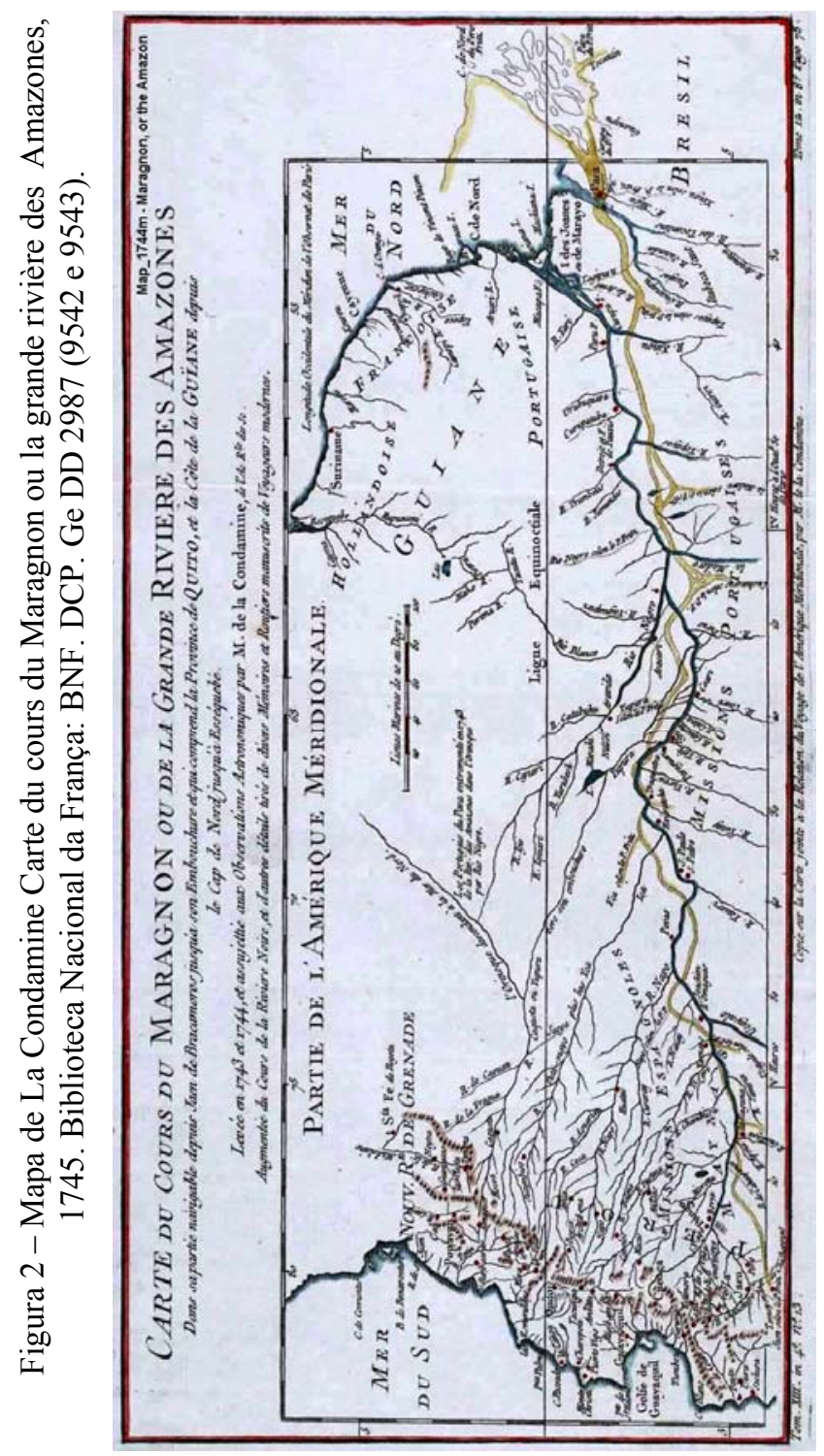

Bol. Ciênc. Geod., sec. Artigos, Curitiba, v. 18, nº 3, p.421-445, jul-set, 2012. 


\section{O MAPA DAS CORTES}

\subsection{O Mapa e seu Conteúdo}

Em 1749, foram elaborados dois mapas idênticos para servirem de base para o Tratado de Madri (1750): um ficou com a Espanha, e o outro, com Portugal; esse último foi encontrado em Paris pelo barão do Rio Branco. A partir deles foram feitas três cópias em Lisboa (1751) e enviadas a Madri, sendo que atualmente essas cópias pertencem à Mapoteca do Itamaraty. Por seu turno, foram feitas outras três cópias em Madri e enviadas a Lisboa. Isso explica as diversas versões que se encontram desse mapa, inclusive na Internet.

Como é sabido, esse Mapa (Figura 3) que não indica o autor nem o desenhista, prática corrente na cartográfica da época, foi feito em Lisboa, sob a direção de Alexandre de Gusmão, com base em todo o conhecimento cartográfico acumulado.

Projeção e escala são duas informações importantes que não constam do mapa À primeira vista, parece tratar-se de uma carta plana quadrada ou Plate carrée, projeção utilizada pelos portugueses e que consiste numa rede retangular de meridianos e paralelos com igual espaçamento e escala nas duas direções. Essa impressão é causada porque as bordas graduadas (em princípio meridianos) são perpendiculares ao equador e à linha do trópico. Verifica-se também a igualdade entre as graduações de longitude no equador e as de latitude nas duas bordas laterais. Mas há um elemento que desautoriza classificar essa projeção como carta plana quadrada: a graduação do paralelo inferior (latitude de $36^{\circ}$ ) possui um tamanho menor que as demais e o coeficiente de redução é de 0,94 , ou seja, $6 \%$ menor. Assim, até o momento não foi possível identificar positivamente a projeção utilizada. Mas para efeitos práticos, foi possível medir longitudes como se fosse uma carta plana quadrada e aplicar uma redução em função da latitude (de 0 a 6\%).

Outra incógnita do mapa é o meridiano de origem. A razão mais forte para isso era a de evitar discussões em torno da linha de Tordesilhas, que foi igualmente omitida. Apesar das tentativas não foi possível determinar o meridiano de origem desse mapa. Poderia ter sido o meridiano de Paris, já que esse foi a origem das coordenadas medidas pelos padres matemáticos: Diogo Soares e Domingos Capassi tomaram como origem esse meridiano por disporem das tábuas de Cassini, elaboradas para esse observatório, com a previsão das efemérides dos satélites de Júpiter. Ainda que, como esses padres mediram também a longitude do Rio de Janeiro (Morro do Castelo), poderiam facilmente transformar todos os dados para essa referência, por simples subtração.

O mapa apresenta uma coloração geral sépia, acentuada pelo tempo. Como consta da minuta do verso, a linha de divisa contínua é de cor vermelha: inicia-se em Castilhos Grandes ao sul, no atual Uruguai, e termina ao norte na presumível e incerta divisa do Brasil com as antigas Guianas. Existem leves aguadas para indicar áreas ocupadas por portugueses (amarelo) ou espanhóis (rosa), como se pode ler na cartela, coisa que aponta também para o princípio do uti possidetis. Tanto os meridianos extremos, como o equador e os paralelos estão graduados de três em três 
graus, alternando trechos escuros e claros. A linha do trópico desenhada em tom avermelhado não possui graduação. $\mathrm{O}$ interior dos rios de margem dupla, de lagos e de pântanos possui uma cor sépia mais intensa, como ocorre também na zona costeira. Há duas belas rosas-dos-ventos, ambas de mesmo desenho e terminadas por uma flor de Liz: uma acima da baía de São Luis e outra na altura de Paranaguá, ocupando posições esteticamente convenientes.

Figura 3 - Mapa das Cortes ou Mapa dos confins do Brasil com as terras da coroa de Espanha na América Meridional, 1749. Fonte: Fac-simile do original da Biblioteca Nacional.

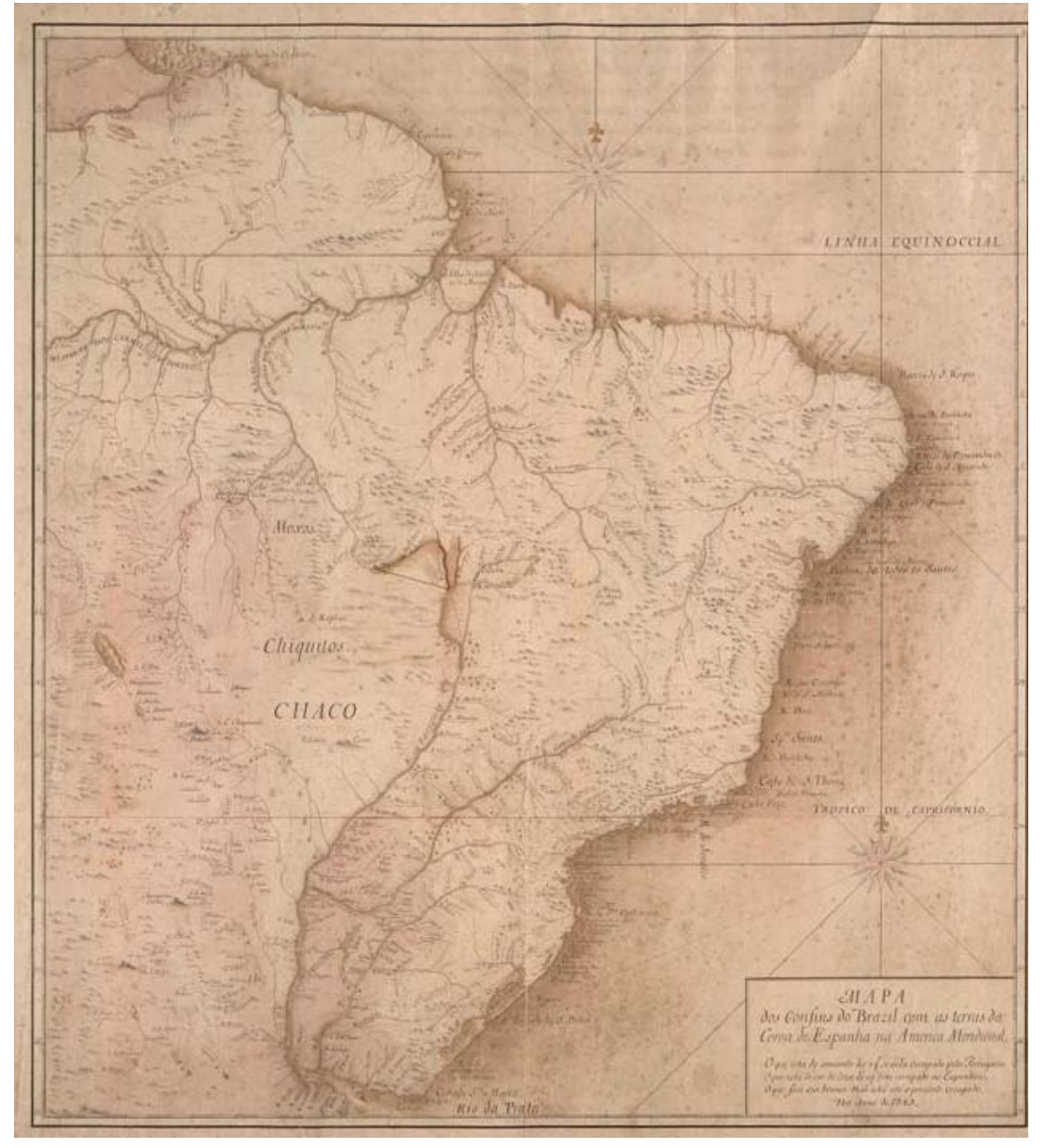

Bol. Ciênc. Geod., sec. Artigos, Curitiba, v. 18, nº 3, p.421-445, jul-set, 2012. 
Os topônimos em solo brasileiro estão grafados em português da época, com algumas abreviações, enquanto os da América espanhola estão em castelhano, contaminado às vezes pelo português; alguns nomes estão grafados totalmente em maiúsculas: Linha equinoccial, Tropico de capricornio, as Missoes dos Carmelitas ou dos Jesuítas. Também em maiúsculas, mas em tamanho exagerado, estão as missões de Chiquitos e Moxos e a região do Chaco; como se verá, isso se deve à necessidade de ocupar o espaço em branco deixado pelo deslocamento proposital do Pantanal. Não existe uma legenda com as convenções cartográficas, como seria próprio de um mapa moderno, mas há o que se poderia chamar de simbologia natural: montanhas e cerros em perspectiva; pequenas lagoas para indicar uma região de lagos; conjunto de árvores para representar matas; conglomerado de pequenas ilhas para representar arquipélagos; formas circulares preenchidas de vermelho para indicar povoações, às vezes encimadas por bandeirolas (em geral representam fortes) ou cruzes (nesse caso, missões) ou constituídas por uma pequena edificação coroada por uma cruz (nesse caso cidades ou vilas de certo porte, com igreja matriz).

\subsection{Análise Morfológica Preliminar}

Ao olhar para o Mapa das Cortes, a reação espontânea é dizer que se trata de um mapa rudimentar: pelas cores, diferentes das usuais em mapas; pela ausência dos limites interiores e por apresentar, em alguns locais, morfologia diferente da dos mapas atuais. Essa última característica é, em parte, explicável por se utilizar uma projeção cartográfica diferente das usuais nos Atlas modernos.

Mas, a simples comparação visual com um bom mapa do Brasil, mostra diferenças que não se explicam só por isso: por exemplo, a posição do Pantanal, situado no meridiano de Belém; a colocação de Recife como ponto extremo leste do Brasil; a forma vertical alongada da Ilha de Marajó; a simplificação da costa norte, que na realidade é repleta de ilhas e reentrâncias; a direção quase vertical dos afluentes da margem direita do Amazonas, quando na realidade todos, a partir do Xingu, correm em direção sudeste para suas nascentes; a direção do Madeira, que é desviado para leste e não para oeste como deveria ser; todos esses afluentes são também encurtados em latitude, fazendo com que as missões castelhanas entre Moxos e Santa Cruz de la Sierra estejam situadas mais ao norte da posição real; a linha Paraná-Paraguai está desviada para leste, fechando-se com a linha do MadeiraMamoré-Jauru no Pantanal e a linha Tocantins-Araguaia, que está deslocada para leste.

Ainda com relação a rios, há inversões de alguns deles, como o Menim e o Tapicuru (na baía de São Luís) ou o Inhambupe com o Tapicuru (na Bahia). Erros de maior vulto são a colocação do Beni como formador ou tributário do Purus e não do Madeira; a colocação do rio Parnahiba (Piauí) na baía de São Luís; a transformação de rios em braços de outros e erros no tamanho, e importância relativa de afluentes como, por exemplo, nos formadores do rio Paraná. 
Com relação às localidades (vilas, cidades, fortes), há muitas que são colocadas sem nome: quatro no vale do Paraíba do Sul, outras na costa do Rio Grande do Sul (as diversas povoações ocupadas cada uma por 60 casais) e algumas ao longo do Amazonas; alguns fortes possuem a letra F (de Forte) depois do nome (Gurupá, Macapá), o que provém do fato de esse trecho ter sido copiado do mapa de La Condamine. Algumas vilas do interior, destacadas em função da mineração, também aparecem em posição errônea: Cuiabá, Goyas (Velho), Mariana, Vila Rica (Ouro Preto) e Vila do Príncipe (Cerro).

\subsection{Análise Morfológica Quantitativa}

Uma comparação quantitativa foi desenvolvida em Cintra (2009). Para isso, utilizou-se um programa de Cartografia digital (MapInfo) para extrair as coordenadas, o que possibilitou gerar diversas tabelas de coordenadas de pontos para compará-las com as coordenadas-padrão obtidas da Carta do Brasil ao milionésimo produzida pelo IBGE em 46 folhas de papel, hoje disponíveis em meio digital (IBGE,1999). Como o próprio nome indica, está na escala 1:1.000.000, que é cerca de 7 vezes maior, com mais detalhes e mais precisa que o Mapa das Cortes. Os cálculos e análises estatísticas foram feitos em planilha eletrônica (Excel), com os dados extraídos pelo programa de Cartografia digital. No total, foram quantificadas as diferenças em cerca de 430 pontos, número considerado suficiente para a análise.

A primeira tarefa, quase um quebra-cabeça, foi o estabelecimento da correspondência entre os acidentes geográficos do Mapa das Cortes e do Mapa atual do IBGE. Uma vez identificados os pontos homólogos, bem definidos nos dois documentos cartográficos, passou-se à fase de extração das duas coordenadas, latitude e longitude, nas duas fontes. Para facilitar os cálculos, as coordenadas foram expressas em grau e fração (sistema decimal) e não em graus e minutos (sistema sexagesimal).

Tabelas de diferenças de coordenadas (em latitude e longitude); gráficos e alguns indicadores estatísticos foram gerados para permitir as análises e a síntese final. Para o registro do mapa em longitude foi tomado como referência o meridiano do Rio de Janeiro, (antigo Morro do Castelo, com 43,18 em relação a Greenwich).

O Mapa foi dividido em regiões homogêneas e, os erros e os resultados são apresentados na Tabela 1 e comentados na seqüência.

Nessa tabela, o conteúdo das colunas "erro sistemático" resulta da aplicação do teste de hipóteses $\left(\chi^{2}\right)$ que verifica se determinado valor (a média dos deslocamentos) é estatisticamente significativo ou não. Em caso afirmativo, indicase quanto é esse deslocamento. O conteúdo das colunas precisão corresponde ao desvio padrão da amostra. A seguir, comentam-se os valores dessa Tabela, para cada uma das 6 regiões. 
Tabela 1 - Análise estatística do Mapa das Cortes por regiões homogêneas quanto

\begin{tabular}{|c|c|c|c|c|c|}
\hline \multirow[t]{2}{*}{ Região } & \multirow{2}{*}{$\begin{array}{l}\text { No. de } \\
\text { pontos }\end{array}$} & \multicolumn{2}{|c|}{$\begin{array}{l}\text { Latitude } \\
\end{array}$} & \multicolumn{2}{|c|}{ Longitude } \\
\hline & & $\begin{array}{c}\text { Erro } \\
\text { sistemático }\end{array}$ & Precisão & $\begin{array}{c}\text { Erro } \\
\text { sistemático }\end{array}$ & Precisão \\
\hline $\begin{array}{l}\text { 1. Costa Atlântica } \\
\text { (toda) }\end{array}$ & 117 & \multirow{5}{*}{ Não } & \multirow{5}{*}{$0,22^{\circ}$} & \multicolumn{2}{|c|}{ Não calculado } \\
\hline $\begin{array}{l}\text { a) S. Maria a São } \\
\text { Roque }\end{array}$ & 72 & & & Não & $0,37^{\circ}$ \\
\hline $\begin{array}{c}\text { b) São Roque - } \\
\text { Acaraú }\end{array}$ & 9 & & & Sim: $1,62^{\circ}$ & $0,11^{\circ}$ \\
\hline $\begin{array}{l}\text { c) Acaraú - } \\
\text { Camocim }\end{array}$ & 3 & & & Sim: $2,50^{\circ}$ & - \\
\hline $\begin{array}{l}\text { d) Camocim - } \\
\text { Cabo Orange }\end{array}$ & 32 & & & Sim: $3,22^{\circ}$ & $0,31^{\circ}$ \\
\hline $\begin{array}{l}\text { 2. Amazonas e } \\
\text { afluentes }\end{array}$ & 31 & \multirow{3}{*}{ Não } & \multirow{3}{*}{$0,14^{\circ}$} & \multicolumn{2}{|c|}{ Não calculado } \\
\hline a) Belém a Manaus & 20 & & & Não & $0,35^{\circ}$ \\
\hline b) Na foz do Javari & 1 & & & Sim: $2,60^{\circ}$ & - \\
\hline $\begin{array}{l}\text { 3. Madeira- } \\
\text { Guaporé }\end{array}$ & 25 & Sim: $2,98^{\circ}$ & $0,82^{\circ}$ & Sim: $6,81^{\circ}$ & $1,16^{\circ}$ \\
\hline 4. Paraná - Jauru & 36 & \multicolumn{2}{|c|}{ Não calculado } & \multicolumn{2}{|c|}{ Não calculado } \\
\hline a) Prata - Apa & 20 & Não & $0,50^{\circ}$ & Não & $0,54^{\circ}$ \\
\hline b) Apa - Jauru & 16 & Sim: $2,36^{\circ}$ & $0,20^{\circ}$ & Sim: $3,56^{\circ}$ & $0,59^{\circ}$ \\
\hline $\begin{array}{l}\text { 5. América } \\
\text { espanhola }\end{array}$ & 53 & \multicolumn{2}{|c|}{ Não calculado } & \multicolumn{2}{|c|}{ Não calculado } \\
\hline $\begin{array}{l}\text { a) Venezuela e } \\
\text { Guianas }\end{array}$ & 14 & Sim: $0,79^{\circ}$ & $0,88^{\circ}$ & Sim: $3,12^{\circ}$ & $0,93^{\circ}$ \\
\hline $\begin{array}{c}\text { b) Missões } \\
\text { jesuíticas (MT) }\end{array}$ & 8 & Sim: $4,51^{\circ}$ & $1,55^{\circ}$ & Sim: $3,08^{\circ}$ & $1,43^{\circ}$ \\
\hline $\begin{array}{c}\text { c) Cusco - Buenos } \\
\text { Aires }\end{array}$ & 31 & Não & $0,51^{\circ}$ & Sim: $1,03^{\circ}$ & $1,07^{\circ}$ \\
\hline $\begin{array}{l}\text { d) Missões no } \\
\text { Paraguai }\end{array}$ & 24 & Não & $0,13^{\circ}$ & Não & $0,48^{\circ}$ \\
\hline \multicolumn{6}{|l|}{$\begin{array}{c}\text { 6. Bacias e vilas } \\
\text { interiores }\end{array}$} \\
\hline a) Tocantins & 13 & Sim: $2,22^{\circ}$ & $1,50^{\circ}$ & Sim: $1,76^{\circ}$ & $2,29^{\circ}$ \\
\hline $\begin{array}{l}\text { b) Uruguai - } \\
\text { Paraná }\end{array}$ & 46 & Não & $0,59^{\circ}$ & Sim: $0,88^{\circ}$ & $0,81^{\circ}$ \\
\hline
\end{tabular}




\subsubsection{A costa atlântica}

Foram coletados 117 pontos, do Oiapoque ao cabo de Santa Maria, incluindo também o estuário do Prata, Montevidéu, Buenos Aires e Colônia Sacramento.

Em latitude, não há erro sistemático, e a precisão dos resultados é $0,22^{\circ}$, valor que pode ser considerado bom para a época. Como é sabido, foi possível contar com coordenadas precisas, levantadas pelos padres matemáticos, desde a Colônia Sacramento até o Cabo Frio; o resultado, para esse trecho menor (28 pontos), mostrou uma precisão de $0,14^{\circ}$, resultado melhor que o do conjunto e que não consta nessa Tabela por simplificação.

Para a longitude, dividiu-se a região em quatro, em função da homogeneidade dos erros. A primeira, do cabo de São Roque ao cabo de Santa Maria (72 pontos), em que não há erro sistemático e a precisão é de $0,37^{\circ}$, pior que o erro em latitude como esperado em função da dificuldade muito maior para medir essa coordenada mas o valor é bom para a época; a região medida pelos padres matemáticos, não constante da Tabela, tem uma precisão um pouco melhor $\left(0,30^{\circ}\right)$. Isso significa que as coordenadas da costa brasileira, em todo esse trecho, seguem muito de perto os valores reais. Na segunda região, do cabo ou baixos de São Roque (RN) até o Ceará, já a partir da Ponta de Galinhos (e rio Guamaré, RN) e até o rio Mundaú (CE), detecta-se que as longitudes apresentam um erro sistemático de $1,62^{\circ}$, com precisão de $0,11^{\circ}$. Isso significa que foi introduzida uma distensão consistente e invariável $\left(1,62^{\circ}\right)$ nesse trecho. A terceira região, que vai do rio Acaraú (Aquirás) ao Camocim (rio de São Francisco, no $\mathrm{CE}$ ), apresenta erros de longitude que crescem gradativamente de $2,0^{\circ}$ a $2,5^{\circ}$, ou seja, nesse trecho é introduzida uma distensão adicional de mais $0,9^{\circ}$. A quarta região (32 pontos) que vai do rio Camocim ao Cabo Orange (AM) apresenta um erro sistemático médio de $3,2^{\circ}$, com precisão de $0,31^{\circ}$. Isso significa mais $0,7^{\circ}$ de nova distensão, e um total superior a $3^{\circ}$, valor que se atinge em Belém do Pará.

Depois dessa analise, fica desvendada e quantificada a primeira distorção do Mapa das Cortes: uma distensão de $3^{\circ}$ no total acumulado e convenientemente distribuído ao longo da costa leste-oeste, do cabo de São Roque a Belém do Pará.

Diversos argumentos descartam a possibilidade de esses erros serem fortuitos ou acidentais. Em primeiro lugar, a boa precisão em latitude $\left(0,22^{\circ}\right)$ e longitude $\left(0,37^{\circ}\right)$, indica que os portugueses possuíam conhecimentos e técnicas para medir bem essas coordenadas e desenhar mapas com essa precisão, não havendo justifica técnica para erros da ordem de $3^{\circ}$; depois, o fato de que a determinação de coordenadas é, em princípio, independente das demais: um erro grande num ponto seria detectado em algum dos seguintes e poderia ser corrigido. Finalmente, o fato de o mapa de D'Anville, produzido um ano antes sob a supervisão de Portugal, possuir valores corretos para esses pontos. Ou seja, um erro crescente para oeste a partir do cabo de São Roque não pode ser obra do acaso. Além disso, esse deslocamento era obrigatório para poder colocar a linha de Tordesilhas em consonância com o mapa de Delisle (aproximadamente de Belém ao Rio Grande de São Pedro) e com todos os mapas posteriores a esse, que reconheciam, perante a 
Espanha, essa nova posição ao norte e ao sul ficou sendo praxe. Mas, mesmo assim, ainda é bastante favorável a Portugal com relação à posição real (meridiano passando por Imbituba/Laguna ao sul). $\mathrm{O}$ valor do erro $\left(3^{\circ}\right)$ também coincide com o erro, acidental ou não, de La Condamine na região amazônica, como se verá.

\subsubsection{O rio Amazonas e seus afluentes}

Nessa região, o Mapa das Cortes coincide com o de La Condamine, em princípio fora de suspeita para os espanhóis. Para a comparação das coordenadas desse rio com os valores reais (IBGE, 1999) foi feito um estudo (CINTRA e FREITAS, 2011), tomando-se 31 pontos comuns, em geral a foz dos afluentes, fortes e aldeias. A análise em latitude revelou não haver erro sistemático e uma precisão de $0,14^{\circ}$, com exceção da Ilha de Marajó, que está alongada de $0,7^{\circ}$ para 0 sul, erro que se reflete no Tocantins e demais rios abaixo dessa ilha. Revelou-se, em longitudes, que até Manaus não há erro sistemático, com uma precisão de $0,35^{\circ}$ (valor coerente com o resto do mapa); mas, a partir daí, há erros que vão crescendo sistematicamente em direção a oeste: $0,8^{\circ}$ no Purus e Coari; $1^{\circ}$ no Juruá; $1,5^{\circ}$ no Jutaí; $1,7^{\circ}$ em São Paulo de Olivença, para terminar com $2,6^{\circ}$ no Javari. Ora, esse novo erro (negativo) tem dois efeitos: diminui em $2,6^{\circ}$ a extensão da ocupação portuguesa na Amazônia, a partir de Belém, e desconta bastante os $3^{\circ}$ de erro nessa cidade, devolvendo as coordenadas ao seu valor quase correto (em termos absolutos), quando se entra em território espanhol (diferença de $0,4^{\circ}$ ).

Em resumo, o rio Amazonas, de Belém até a fronteira, fica encurtado de uns $3^{\circ}$, compensando a dilatação de Belém sobre o Rio de Janeiro, cujo ajuste é favorável a Portugal, pois apresenta o território do vale amazônico como mais curto na direção leste-oeste do que na realidade é.

\subsubsection{A linha Madeira-Guaporé}

A peça-chave para entender a deformação geral das divisas a oeste é começar examinando o deslocamento das minas de Cuiabá: $2,5^{\circ}$ para norte e $4^{\circ}$ para leste, situando-se praticamente no meridiano de Belém (Tordesilhas), o que arrasta consigo o Pantanal (que está quase na posição do Distrito Federal) e o traçado dos rios associados: Guaporé, Madeira, Jauru, Paraguai e Paraná. Além disso, o deslocamento para o norte reduz a dimensão norte-sul da região amazônica pretendida pelos portugueses. Para quantificar as deformações na linha MadeiraGuaporé, foram tomados 25 pontos. Em latitude, existe um erro sistemático de $3^{\circ}$ de deslocamento para o norte e, em longitude $6,8^{\circ}$ para leste, ou seja, para dentro da linha divisória. Disso resulta que o rio Madeira, com boas coordenadas na sua foz e na barra do rio Abacaxis, em vez de seguir o curso sudoeste para montante, segue na direção sul por uns $2^{\circ}$ e depois deflete acentuadamente para sudeste. Vale lembrar que o ponto médio do Madeira, junto às primeiras cachoeiras, era o ponto de inflexão da linha vermelha de divisa do Tratado, que devia buscar o Javari, segundo uma linha leste-oeste. Em função desse giro, os erros são muito grandes: no entroncamento do Madre de Dios, Beni e Mamoré (formando o Madeira), o erro é 
de $2,6^{\circ}$ em latitude (colocado mais ao norte do que deveria estar) e, em longitude, $4,9^{\circ}$ para leste, ou seja, colocado mais para dentro do Brasil. Esses valores influenciam os grandes erros encontrados nas coordenadas das missões jesuíticas espanholas entre os índios moxos. O rio Guaporé dirige-se para sudeste, menos do que na realidade, resultando em um erro de $1,7^{\circ}$ em latitude e $3,1^{\circ}$ em longitude, na barra do rio Sararé, ponto por onde passa a linha divisória vinda da boca do Jauru.

\subsubsection{A linha Paraná-Jauru}

A análise de 36 pontos nessa região foi subdividida em duas amostras: uma aproximadamente do rio da Prata ao Apa, e outra desse ponto para cima, até a boca do Jauru, no Paraguai. No primeiro trecho, para as duas coordenadas não há erros sistemáticos, ainda que as medições tenham certa imprecisão $\left(0,5^{\circ}\right)$. Já no segundo trecho, existem erros sistemáticos: $2,4^{\circ}$ em latitude e $3,6^{\circ}$ em longitude. A análise pontual mostra que em longitude há erros flutuantes, refletidos no valor da precisão $\left(0,6^{\circ}\right)$ e que são cumulativos para leste, atingindo $0,9^{\circ}$ em Assunção; $1,4^{\circ}$ no rio Apa; $2,5^{\circ}$ no segundo Corrientes; $3,8^{\circ}$ no Taquari e $3,9^{\circ}$ no Jauru. Camapuã, povoação no caminho fluvial para Cuiabá, com erro quase nulo em latitude, apresenta erro de $3,1^{\circ}$ em longitude. As nascentes do Paraguai, Jauru e Guaporé são deslocadas, para o norte, de uns $7^{\circ}$, situação de compatibilidade com a diminuição da extensão norte-sul da bacia amazônica, com um encurtamento notável do Tapajós e seus formadores: Juruena, Arinos e Teles Pires.

\subsubsection{América espanhola e missões}

Essa região foi dividida em quatro conjuntos, que possuem como característica comum o fato de apresentarem baixa precisão em ambas as coordenadas e refletem, de certa maneira, a cartografia espanhola da época. Em quase todas elas existe também um erro sistemático em todas as coordenas. A região da Venezuela e das Guianas apresenta erros pequenos na foz dos rios no Atlântico, mas valores crescentes nos pontos interiores; em longitude; os erros acompanham aproximadamente os $3^{\circ}$ de Belém, havendo um ponto no interior com erro de $4,8^{\circ}$. $\mathrm{Na}$ região das missões jesuíticas, que confrontam com o atual estado de Mato Grosso, os erros são muito grandes: $4,5^{\circ}$ e $3.1^{\circ}$ em latitude e longitude, respectivamente. De Cusco a Buenos Aires, embora relativamente impreciso, não existe erro sistemático em latitude e um erro sistemático de $1,0^{\circ}$ para leste, que afeta, por exemplo, a região do lago Titicaca. No entanto, apesar das médias razoáveis, há pontos com grandes erros: $4,1^{\circ}$ em Cusco, $2,5^{\circ} \mathrm{em}$ Salta e $1,9^{\circ} \mathrm{em}$ Chuquisaca, atual Sucre. Por fim, foram analisadas as missões jesuíticas no atual Rio Grande do Sul (São Borja, Santo Ângelo e outras), da região argentina de Misiones (S. Tomé, Santo Inácio e outras) e do Paraguai (S. Tiago, Tobati e outras), num total de 24 pontos. Não há erros sistemáticos significativos e a precisão é razoável.

De qualquer forma, deve-se ter em conta que as coordenadas em território claramente espanhol pouco importam na disputa e devem ter sido tomadas de fonte 
espanhola, para evitar qualquer problema. Por exemplo, uma das fontes utilizadas deve ter sido o Mapa dos jesuítas denominado Paraquariae Provinciae Soc. Jesu cum adjacentib(us) novíssima descript(io), de 1732. Uma simples comparação visual já permite essa conclusão: há uma semelhança muito grande nos detalhes: formas geométricas, localidades representadas e limite ao sul absolutamente coincidentes, além de uma linha vermelha de limites, não muito diferente ao sul e a oeste, até o Pantanal

\subsubsection{Bacias e vilas interiores}

Nessa categoria, destacam-se as bacias do Tocantins, São Francisco, Uruguai e Paraná. A do Tocantins, com 13 pontos, apresenta erro sistemático e grande variabilidade dos erros (baixa precisão). Sua posição fica condicionada pelos deslocamentos do Pantanal e de Belém. Com a foz próxima dessa cidade, esse rio tem seu curso desviado para oeste, a fim de ter suas nascentes próximas das bacias vizinhas que estão em posição correta e assim não deixar espaços vazios. Quantificando, os desvios em longitude chegam ao valor de 3,9 ${ }^{\circ}$. Em função da posição deslocada do Pantanal, os afluentes da margem esquerda não têm espaço para serem desenhados e ficam encurtados de $4,1^{\circ}$ em latitude. A direção real é muito próxima da linha norte-sul, enquanto o Mapa das Cortes apresenta uma inclinação para sudeste muito acentuada, para evitar a superposição com a região de Cuiabá.

Já a bacia do São Francisco, não constante da Tabela, sofre uma distorção suficiente para acompanhar a deformação da costa, que vai do Rio Grande do Norte a Belém do Pará, ou seja, uma distensão de $3^{\circ}$ no trecho quase leste-oeste desse rio.

Outro grupo de pontos situa-se na bacia Uruguai-Paraná, incluindo o rio Tietê e seus tributários: são 46 pontos determinados pela barra dos afluentes. Em latitude, não há erro sistemático, mas a precisão é de $0,6^{\circ}$; em longitude, há um erro sistemático de $0,5^{\circ}$, para oeste e uma precisão de $0,8^{\circ}$. Para a maioria desses pontos, não há coordenadas determinadas astronomicamente, mas só estimativas por distâncias percorridas a pé, ou em canoa. Assim, muito fora de posição, há alguns rios que são os responsáveis por esses valores que diminuem a precisão da média. São eles: Piqueri, Iguatemi, Ivinhema, Paranapanema, Pardo, Verde, Sucuruí, Tietê, Grande, Moji-Pardo; além de erros, na casa dos $3^{\circ}$, nas nascentes dessa bacia. Erros de toponímia são: chamar de rio Grande o Paranaíba e de Sapucaí o Grande; o Pardo é substituído pelo seu afluente Moji.

Quanto às vilas, também não incluídas nos cálculos, há um grupo interessante de 14, no interior do país, com deslocamentos bastante variados: Moji e Curitiba apresentam erro quase nulo em ambas as coordenadas; Taubaté, Jundiaí, Cachoeira (Paulista) e São Paulo apresentam erro desprezível em latitude, e um erro aceitável (até $0,6^{\circ}$ ) em longitude; outras apresentam erro em longitude da mesma ordem de grandeza, mas valores acentuados em latitude, como é o caso de Vila do Príncipe (Serro, $4,1^{\circ}$ ), Vila Rica (Ouro Preto; $3,0^{\circ}$ ) e Mariana $\left(2,8^{\circ}\right)$. Esses erros no interior não influem na avaliação de fronteiras e estão coerentes com o erro no rio Doce que, 
no Mapa das Cortes, desenvolve-se em direção ao norte, quando deveria ser em direção ao sul. Meia Ponte (Pirenópolis) também segue o erro do contexto, que é o desvio da bacia do Tocantins para a direita, mas existem alguns casos que merecem destaque por sua intencionalidade e magnitude. Em primeiro lugar, Goiás [Velho], que apresenta um erro muito grande em relação à posição real, situando-se muito ao norte $\left(5,2^{\circ}\right)$ e muito a leste $\left(4,7^{\circ}\right)$, no interior da Bahia, erro que não seria de esperar, por duas razões principais: por se contar com coordenadas medidas pelos padres matemáticos, que em geral são muito boas e por estar colocado junto ao afluente mais a leste do Tocantins, quando se sabe (e se sabia na época) que sua posição é nas margens do rio Vermelho, um dos afluentes do Araguaia; mas, caso fosse colocado assim, ficaria bem a oeste do meridiano de Tordesilhas e a oeste mesmo da Cuiabá desse mapa. Ou seja, pelas deformações gerais introduzidas no mapa, tinha mesmo que ser deslocada para leste. Vale repisar que Cuiabá, possível pomo de discórdia, sofre um deslocamento de $2,5^{\circ}$ para norte e $4,0^{\circ}$ para leste e assim situa-se dentro da linha de Tordesilhas. O local de Vila Bela da Trindade e minas de Mato Grosso, com um deslocamento de $1,8^{\circ}$ para o norte e $3,1^{\circ}$ para leste, fica sendo a única área de mineração colocada claramente em território espanhol.

\subsection{Comparação com Outros Mapas}

O confronto com fontes cartográficas mais antigas é mais um argumento que confirma a intencionalidade dos erros. Em primeiro lugar, tem-se o mapa solicitado por Alexandre de Gusmão a Freire de Andrade, denominado Descripçam do Continente da América Meridional, de 1746, que foi também um mapa síntese. Esse, em contraposição ao Mapa das Cortes, apresenta um curso muito mais próximo do real para os rios Tocantins-Araguaia, Madeira-Mamoré-Guaporé, e também situa o Pantanal em posição mais acertada. E, quanto à descrição, já sugere uma divisão entre as duas coroas, próxima da que foi acertada no texto do Tratado.

Depois, o Mapa de D’Anville, de 1748 (com versão preliminar de 1742), encomendado pelo diplomata português Dom Luis da Cunha e feito com as informações que esse foi fornecendo ao cartógrafo francês. Neste mapa, anterior ao Mapa das Cortes, há informações melhores (São Francisco, Madeira, Mamoré, Grande e Paranaíba), coordenadas muito mais precisas, e algumas delas cruciais, como a da boca do Jauru, as do Pantanal (quase na posição correta), Goiás (a $1,5^{\circ}$ a oeste da linha de Tordesilhas e não $6,5^{\circ}$ a leste como no Mapa das Cortes), Cuiabá ( $5^{\circ}$ a oeste dessa linha, e não $0,5^{\circ}$ a leste). Ou seja, a informação havia, mas não convinha empregá-la no Mapa que serviria como base do Tratado.

\subsection{Como Foi Elaborado o Mapa das Cortes}

A quantificação dos erros, como feita acima, permite avançar a forma como foi elaborado o Mapa das Cortes sob os auspícios de Alexandre de Gusmão, articulador do Tratado.

Em primeiro lugar, foram lançados todos os pontos da costa leste, da Colônia Sacramento ao Cabo de São Roque, em que, como se mostrou, os erros são 
pequenos. A seguir lança-se imaginariamente e não no papel, a linha de Tordesilhas passando pela altura do Rio Grande de São Pedro e ao mesmo tempo desenha-se Belém do Pará um pouco à direita dessa linha ao norte, ou seja, segue nesse ponto o mapa de Delisle.

Ao desenhar a linha que une Belém ao Cabo de São Roque surge com conseqüência a distensão da costa leste-oeste de uns $3^{\circ}$. Com isso, cria-se um vazio dessa magnitude no interior do Brasil, na região central e nordeste e provoca cartograficamente o desvio da bacia do Tocantins, levando consigo Goiás e também a bacia do alto Paraguai e Pantanal, transferidas para o planalto central, arrastando também Cuiabá e a linha Guaporé-Madeira, que são deslocadas para o norte e oeste. Isso cria a necessidade da inversão do curso de todos os afluentes da margem direita do Amazonas, para ocupar o espaço aberto por esse deslocamento.

A construção da região norte se dá da seguinte forma: a ampliação de $3^{\circ}$ da costa leste-oeste permite um encurtamento longitudinal de $3^{\circ}$ do vale amazônico, em consonância com o mapa de La Condamine, fazendo com que a soma de ambas tenha um erro nulo e devolvendo assim as longitudes aos seus valores reais ao entrar em território espanhol. Esse encurtamento leste-oeste soma-se à diminuição da dimensão norte-sul desse vale advinda do deslocamento do Pantanal para o norte e do encurtamento dos afluentes amazônicos, como apontado.

Para completar o mapa, desenham-se os elementos restantes que não afetam a região de fronteira: a América espanhola, as bacias e vilas interiores do Brasil. Mas, resta ainda um problema: com o deslocamento do Pantanal, cria-se um vazio entre a região do atual Mato Grosso e as terras atuais de Paraguai e Bolívia, precisamente a zona do Chaco, que está muito aumentada. Para preencher o vazio criado, o recurso foi ampliar os textos, escrevendo em letras muito grandes: Chaco, e um pouco menores o nome das missões situadas nas imediações: Chiquitos e Moxos. É de se imaginar que a Espanha não tinha muita noção das reais dimensões dessa região. A Figura 4 sintetiza as deformações havidas.

\subsection{O Mapa e seu Efeito}

Durante as negociações, houve um momento oportuno em que o representante português conseguiu mostrar o mapa que o negociador espanhol se recusava a ver, por preconceitos. Mas, depois que cedeu a essa solicitação, a impressão e a acolhida foram ótimas, a julgar pelas palavras do mesmo citadas pelo representante lusitano: "(experimentaram) a grande admiração que experimenta um cego quando vê a luz clara" ... "(acabaram) louvando aquele trabalho". Em suma, houve júbilo por parte dos espanhóis por contar com um apoio visual que solucionava dúvidas e permitia discutir as fronteiras sobre um apoio visual. Em duas conferências, com o mapa à vista, ajustaram-se pacificamente os limites, a menos das regiões que incluíam os Sete Povos das Missões, que demandaram um pouco mais de tempo (CORTESÃO, 2006). 
Figura 4 - Contorno atual do Brasil sobre o Mapa das Cortes. A outra linha contínua refere-se às divisas acordadas no Tratado de Madri, em contraposição à linha de Tordesilhas (tracejada). As setas em verde unem a posição verdadeira do local à posição nesse mapa (deslocada). Pode-se notar o pequeno deslocamento de toda a costa, abaixo do Cabo de São Roque.

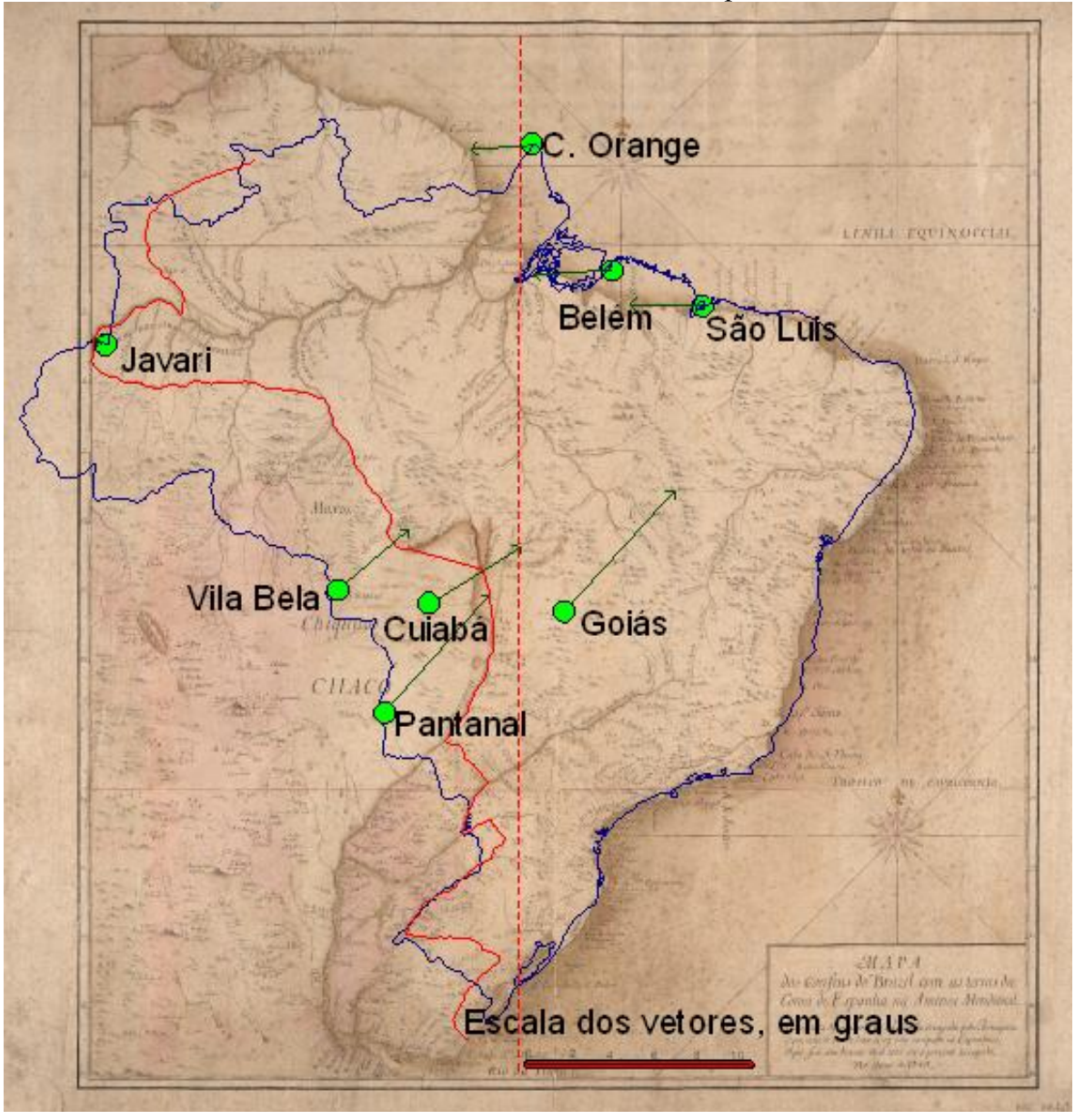

Por outro lado, as duas partes concordaram que o mapa era apenas um mero apoio visual e o que valia era mesmo a descrição das feições que compunham as divisas. Essa afirmação, aparentemente ingênua, pode ter múltiplas interpretações: por um lado, o reconhecimento de que o mapa pode conter erros e é apenas um instrumento, uma ferramenta útil para visualizar e materializar uma descrição; mas 
ao mesmo tempo, no momento da demarcação, obriga ambas as partes a seguirem a letra de um texto, por mais que seja divergente do mapa a ele associado.

A impressão que o mapa passou, e ainda passa, é que haveria uma troca de áreas quase equivalentes: a Colônia Sacramento e seu território (aproximadamente o Uruguai) pelo território dos Sete povos das Missões, medida que assegurava a soberania da Espanha sobre o rio da Prata; concedia-se a Portugal o vale amazônico, que seria uma faixa relativamente estreita em torno desse rio, e que, ao final das contas, seria o reconhecimento de uma situação de fato. Nessa negociação também pesava o fato de, na partição das terras no oriente pela mesma linha indefinida de Tordesilhas, Portugal ter comprado anteriormente os direitos de um território que lhe pertencia (Molucas).

Espanha não tinha uma cartografia melhor para contrapor; as partes se entenderam, aparentemente conseguiram seus objetivos maiores e o tratado foi assinado. O passo seguinte foi a demarcação em campo da nova linha fronteiriça, através de equipes com engenheiros e cientistas dos dois países. Nesse momento, já havia tecnologia para tal e em relativamente pouco tempo viu-se que a área ocupada efetivamente por Portugal era muito maior do que aquela sugerida pelo Mapa das Cortes. Isso, entre outros motivos alegados, foi causa da anulação do Tratado de Madri e a negociação de outros: Santo Ildefonso (1777) e Badajós (1801).

Mas os princípios básicos tinham sido aceitos: a posse efetiva (uti possidetis) e o respeito das fronteiras naturais, como rios e divisores de água. E nesse meio tempo Portugal continuou e acentuou a política de ocupação do território, transferindo a capital do Mato Grosso para Vila Bela da Trindade (1752) e a instalação de fortes ao longo da nova linha de fronteira: Jesus Maria e José (1754), São Gabriel da Cachoeira (1761), São José das Marabitanas (1763), Tabatinga (1766), Conceição (1769), Coimbra (1775), São Joaquim (1775), Príncipe da Beira (1776) e outros, continuando a obra de fatos consumados. Houve modificações, mas nossas fronteiras atuais seguem basicamente aquilo que foi definido em Madri, triplicando aproximadamente a área de nosso país.

\section{CONSIDERAÇÕES FINAIS}

No presente trabalho, depois de mostrar-se a história e a impossibilidade de materializar nossa primeira linha de fronteira, geometricamente resumida num meridiano, comparou-se o Mapa das Cortes com alguns mapas disponíveis na época, cuja importância reside no fato de ter sido o apoio básico para o Tratado de Madri, que definiu praticamente nossas fronteiras atuais. Combinando cartografia histórica com cartografia digital, foi possível quantificar as distorções e concluir, com certeza estatística, que o mapa contém erros propositais em pontos estratégicos.

Além de combinar os princípios de seguir as fronteiras naturais (rios e montanhas) e o das ocupações efetivas (uti possidetis), esse mapa realizou uma montagem cartográfica que fundia, com habilidade, dados e cartas conhecidas e confiáveis para os espanhóis (em geral francesas), a fim de causar uma impressão diminuída das áreas pretendidas pelos portugueses. Mas a falsa impressão não 
poderia durar muito: as expedições demarcatórias iriam apontar as diferenças, o que levou, junto com outros fatores, à anulação do Tratado.

\section{REFERÊNCIAS BIBLIOGRÁFICAS}

ALBUQUERQUE, L. O Tratado de Tordesilhas e dificuldades técnicas da sua aplicação rigorosa. Separata da Revista da Universidade de Coimbra. Coimbra, 1973

BIBLIOTECA NACIONAL. Biblioteca Nacional Digital do Brasil: Projeto Cartografia Histórica dos séculos XVI ao XVIII. http://www.bn.br/bndigital e http://bndigital.bn.br/cartografia/. Último acesso em agosto de 2012

CINTRA, J. P. e FURTADO, J. F.. A Carte de l'Amérique Méridionale de Bourguignon D'Anville: eixo perspectivo de uma cartografia amazônica comparada. Revista Brasileira de História, v. 31, p. 273-316, 2011.

CINTRA, J.P. e FREITAS, J.C. Sailing down the Amazon River: La Condamine's Map. Survey Review, v.43, p.550-566, Oct. 2011.

CINTRA, J.P. O Mapa das Cortes: perspectivas cartográficas. Anais do Museu Paulista, vol. 17, p. 63-77. São Paulo, 2009.

CORTESÃO, A. e MOTA, A.T. da. Portugaliae Monumenta Cartographica, Imprensa Nacional-Casa da Moeda, Lisboa, 1987

CORTESÃO, J. 1955 A fundação de São Paulo, capital geográfica do Brasil, Livros de Portugal, Rio de Janeiro, 1955.

CORTESÃO, J. Alexandre de Gusmão e o Tratado de Madrid, 2v. São Paulo: Imprensa Oficial; Fundação Alexandre de Gusmão, 2006.

CORTESÃO, J. História do Brasil nos velhos mapas. 2v. Rio de Janeiro: Instituto Rio Branco do Ministério das Relações Exteriores, 1965.

GASPAR, Joaquim Alves From the Portulan Chart of the Mediterranean to the Latitude Chart of the Atlantic, PhD Thesis, Universidade de Nova Lisboa, Lisboa, 2010.

IBGE - Carta do Brasil ao milhonésimo, $3^{\mathrm{a}}$ ed. (1999), disponível em: http://www. ibge.gov.br/home/geociencias/cartografia/topo_doc3.shtm

IBGE. Mapa da Amazônia Legal. Rio de Janeiro: Instituto Brasileiro de Geografia e Estatística,1995. Disponível em: <ftp://geoftp.ibge.gov.br/mapas/tematicos>.

LA CONDAMINE, Charles Marie de. Relation Abrégée d'un Voyage fait dans l'interieur de l'Amérique Méridionale depuis la Côte de la Mer du Sud, jusqu'aux Côtes du Brésil \& de la Guiane, en descendant la Riviere des Amazones; lûe à l'Assemblée publique de l'Académie des Sciences, le 28. Avril 1745. Avec une Carte du Maragnon, ou de la Riviere des Amazones, levée par le même, Paris: Veuve Pissot, 1745. Disponível em <http://books.google.com>. [ed. bras.: Viagem na América Meridional descendo o Rio das Amazonas (1745). Brasília: Senado Federal, 2000.

MARQUES, A. P., "Regimento das Léguas", Luís de Albuquerque [dir.], Dicionário de História dos Descobrimentos. Vol. II, Lisboa, Círculo de Leitores, 1994. 
MORAES, Abrahão de. A astronomia no Brasil. São Paulo: Edusp; Instituto Astronômico e Geofísico, 1984.

THEODORO, J e RUIZ, R. São Paulo, de Vila a Cidade, in Porta, Paula (org.) História da cidade de São Paulo, Paz e Terra, São Paulo, 2004

TORDESILHAS, 1494 Tratado de Tordesilhas, disponível em CORTESÃO (1965), ou em http://www.cav-templarios.hpg.ig.com.br/tratado_de_tordesilhas.htm, última consulta em agosto de 2012 .

(Recebido em maio de 2012. Aceito em agosto de 2012.) 